\title{
The Impact of Corporate Sustainability Index on BIST Sustainability Index
}

\author{
By Prof. Ass. Dr. Luan VARDARI ${ }^{1 *}$, Prof. Ass. Rrezarta GASHI ${ }^{2}$, \\ PhD.C. Hana GASHI AHMETI ${ }^{3}$
}

\begin{abstract}
Mass production, which started with the industrial revolution, caused both the unconscious consumption of the resources and the damages to the ecological system after the production. In this respect, the concept of sustainability, which is one of the most important conception of responsibility, is gradually gaining value in terms of protecting resources and transferring them to future generations. (Mori and Christodoulou, 2012: 94-106). Sustainability In the first place, it has started to be used mostly in the management of natural resources; later, it was used in different fields such as sectoral practices and energy tourism (Diaz - Baltciro, Voces, Romero, 2011: 761-773).

Today, the expectations of the society from the enterprises have changed compared to the past. These changing expectations lead businesses to new searches. The most important concept that guides these quests is to be sustainable. The concept of sustainability for enterprises gains a new dimension in the form of corporate sustainability".

For corporate sustainability, it is possible for organizations to achieve individual results only to a certain extent. Because companies are affected to a great extent by all kinds of economic, social and even cultural formations occurring in their environment (Kuşat, 2012: 238).

The most important benefit of sustainability indices is that it leads to improvements in transparency without the need for regulations, better understanding of the social and environmental impacts of companies and guiding them to reduce the negative effects of company activities.

The BIST Index serves as a guide for companies on what to measure, what needs to be developed and what can be explained. Thus, it creates opportunities for companies to see social and environmental risks and opportunities and to manage their sustainability performances correctly. The index, on the other hand, provides information to investors and the community about the sustainability performance of companies.

The aim of this study is whether the BIST Sustainable Index makes a difference for companies compared to BIST 100. "Does the BIST Sustainability Index really make a difference?" will be examined. In this context, data between 2014-2018 of BIST Sustainability and BIST 100 index will be examined. Based on the results obtained in the study, it shows that there is no strong evidence of the impact of inclusion in the BIST Sustainability Index on the stock returns of companies. At the same time, the BIST Sustainability Index has been shown to have similar returns to the BIST 100 Index.
\end{abstract}

Key Words: Sustainability Index, BIST, Corporate.

\section{The Concept of Sustainability}

The concept of global sustainability has emerged with the "Common Future" report, also known as the Bruntland Report, published in 1987 by the World Commission on Environment and Development at the United Nations. In this report, 
the concept of sustainability is based on humanity within the framework of sustainable development; It refers to the ability to make development sustainable without compromising the ability to meet the needs of future generations (Çamlica \& Akar, 2014). The widely accepted definition of sustainability is defined as meeting the needs of today's society without sacrificing its ability to meet the needs of future generations (Özçelik, 2013).

The concept of sustainability for businesses is defined as the management of risks through adaptation of economic, environmental and social factors to the activities and decision mechanism of the enterprise together with corporate governance principles in order to create long-term value (http://www.imkb.gov.tr).

In general, there are many indicators that measure sustainability. However, the Global Reporting Initiative (GRI) represents one of the most comprehensive and well known worldwide. The sustainability performance indicators proposed by GRI are divided into 3 main categories: economic, social and environmental. Each category includes additional performance indicators and information about management, which corresponds to key indicators (Gomes et al., 2014).

The reasons for increasing the importance of sustainability today are as follows: (https://www.pwc.com.tr):

- It is the burden of many social and environmental responsibilities due to the growth of companies from a national structure to very large organizations in an international structure.

- The development of communication technologies (so that companies act responsibly in all geographies in which they operate).

- In making investment decisions, they not only considered the financial performance of the companies, but also their social and environmental performance.

- Thanks to consumer awareness, today's companies have led to behaving in this way and taking responsibility.

- $\quad$ Today, the importance of transparency and accountability of enterprises and the expectations of all stakeholders in this direction include the impact of the activities of the enterprises on the environment and society in general, rather than just disclosing the financial statements of the companies.

- Environmental factors such as climate change at the global level force businesses to be sensitive to this issue.

\section{Corporate Sustainability Concept}

The concept of corporate sustainability has become a very important phenomenon worldwide, especially with the Brundtland Report published by the World Environment and Development Commission (WCED) in 1987. Brundtland Report defines sustainable development as "taking into consideration the needs of future generations while meeting today's human needs". Based on this definition, organizations aiming to be sustainable, use the resources they receive from the environment effectively 
and strive to prevent waste of resources by recycling the goods and services produced (Ozer, 2012).

Sustainability emphasizes not only an efficient distribution of resources over time, but also a fair distribution of resources and opportunities both among the present generation and between present and future generations and economic activities commensurate with its economic life support system (Türker, 2012).

Corporate sustainability can be improved through the implementation of corporate social, economic and environmental sustainability dimensions that can contribute to sustainable development through a wide range of tools for a company (Lozano, 2012). International organizations supporting corporate sustainability The United Nations Global Compact (UNGC) (Perez et al., 2011), the Global Reporting Initiative (GRI), the Sustainable Reporting Guide or International Organization Standards ISO) and ISO 14001 have been initiated by many organizations that guide environmental management. In general terms, corporate sustainability is a business approach that creates long-term value for businesses, creates the continuity of companies by evaluating opportunities arising from economic, social and environmental developments and managing risks (Gözüm and Acar, 2018; Stringer, 2009).

Corporate sustainability is the adaptation of economic environmental and social factors to corporate activities and decision-making mechanisms along with corporate governance principles and management of risks arising from these issues in order to create long-term value in enterprises. It is considered as an emerging management theory that emerged as an alternative to the traditional growth and profit maximization model. Inefficiencies in the current system, weakness in decision-making process, accountability ratio of the system and the lack of institutional sustainability were effective in bringing the concept of corporate sustainability to the agenda (Senal and Ateş, 2012).

Corporate sustainability is considered the equivalent of the sustainability approach at the enterprise level. According to this approach, the corporate growth and profitability of enterprises and their pursuit of social goals such as environmental protection, social equality, justice and economic development are of equal importance. Economic, social and environmental parameters, which are three sub-factors of sustainability, should be included in all basic, strategic and operational processes and decision-making mechanisms of companies for a healthy sustainability practice. It is important to note that companies have responsibilities not only economically but also socially and environmentally. At the enterprise level, it is seen that corporate sustainability is highly correlated with competition, innovation and marketing components. In this respect, any company can gain a competitive advantage over corporate sustainability (Öztel-Köse and Aytekin, 2012).

There are certain forces that force companies to be sustainable. While some of these forces stem from the company's financial concerns, others are approached with a sense of social responsibility which is considered necessary in the formation of a corporate identity; companies are commercial entities and all commercial organizations are profitable. According to this perspective, companies feel responsible for the prevention of environmental degeneration, they do not respond to changing consumer habits especially with their innovations in production and marketing processes or they want to 
exhibit a sustainable vision in order to stay behind from other competing companies in the global formation; as a result, it is aimed at maximizing profit (Kuşat, 2012).

Businesses are focused on increasing their share values for a long time, selling at the lowest cost and highest market price and thus reaching the highest profit. However, because of increasing costs and different measurement techniques in this process, they were reluctant to use technologies to control industrial pollution and ignored their harm to nature. However, customers' demands for sustainable development have led to the consideration of the results of the economic and social activities as well as the economic activities of the enterprises. Because the social and environmental activities of businesses to benefit, products and purchasing process began to affect the preferences of customers (Senal and Fire, 2012).

As mentioned above, with the changes in the role of accounting, businesses have started to think of new tables and report models that improve social and environmental information as well as financial and social information as well as bad news as well as bad news and sustainability reporting has emerged in this process. Sustainability reporting is an application aimed at sustainable development, measuring and explaining corporate performance, and being responsible to internal and external stakeholders. Sustainability reporting is a broad term that is synonymous with triple responsibility reporting to describe reporting on economic environmental and social impacts. The sustainability reports that expand using the GRI (Global Reporting Initiative) Reporting Framework cover the results and results that emerged in the context of the company's commitments, strategy and management approach during the reporting period. These reports are a new communication model that will provide information about corporate sustainability (Senal and Ateş, 2012).

Through accounting, which is one of the basic measurement systems in business life, it is possible to understand and evaluate business activities and results. The financial reports obtained in the accounting information system show the profitability obtained by the efficient use, protection and management of the assets and resources of an enterprise (Çalışkan, 2012). From the perspective of sustainability and business stakeholders, financial accounting, which only concerns the financial aspects of business activities, is insufficient to obtain the expected benefits from reporting. Sustainability accounting and reporting of economic, environmental and social impacts of business activities has been brought up in order to overcome this deficiency (Ho and Taylor, 2007).

The market value of an entity is the reflection of the investors' expectations regarding the current and future values and this value shows itself in the stock price of the company. On the other hand, the book value of the enterprises represents the value of the net assets in the entity's balance sheet and this value, which is included in the financial reports, is the official company value that the firm presents to its shareholders and other business associates. While the market value and book value of firms were close to each other until the end of the 1970s, the difference between these two values is gradually increasing. Intangible assets such as customers, human resources, relations with stakeholders, brands owned and reputation are examples of non-financial elements that determine the market value of businesses. All of these intangible elements are directly or indirectly affected by the results of the economic, social and environmental performance of the business activities. Determining the reasons of the difference between the book 
value determined by the assets given in the financial statements of the enterprises and the market value arising from the effect of the mentioned performance results is important for all stakeholders, especially the owners, managers and investors. Reports, including non-financial information, are important tools to present information about the difference between these two values (Hardworking, 2012).

This concept is briefly expressed as the necessity of reporting of the environmental economic and social impacts of the activities of the operators. According to the English equivalents of the words "planet, people and profit", it is also called "3P". According to this approach, if an enterprise gives equal importance to environmental (planet) social (people) and financial (profit) elements in its operations, it can create more value in the long term than an enterprise that focuses only on profit. It may face less risk and obtain competitive advantages (Çalışkan, 2012).

Businesses that attach importance to corporate sustainability;

- It increases the company's performance through long-term investments rather than short-term thinking of its activities (Kotler and Casoline, 2011).

- Realizes the best practices in economic, social and environmental dimensions (Stringer, 2009).

- It ensures the continuity of the company by managing risks that threaten the entity's existence (Bekmezci, 2014).

- Developed as an alternative to traditional growth theories of institutions with an economic purpose, it minimizes all kinds of material and moral risks and transfers institutions to the future healthier (Kuşat, 2012).

- Corporate sustainability provides benefits such as strengthening the brand position of enterprises, increasing sales and market share, Image and impact of the tripartite organization, attracting qualified personnel to the business, increasing the ability of encouraging and keeping employees in the company, decreasing operating costs and making investors effective in investment decisions against the company (Lee, 2006).

Successful implementation of corporate sustainability by enterprises shows three important results according to Bansal (2005):

\section{Economic Sustainability \\ (profitability, efficiency)}

\section{Social Sustainability}

(Equality, social responsibility)

\section{Environmental sustainability}

(natural resources, environment)

\section{Sustainable Business}


Figure 1. Sustainable enterprise and corporate sustainability dimensions

Source: Yuldi2, 2006.

Environmental Integrity: With the new perspective of the company, the damage to the environment during the production process will be minimized. Environmentally friendly production technologies will develop.

Social Equality: Thanks to the importance that companies attach to the implementation of social responsibility projects, individuals will have equal access to resources.

Economic Welfare: An increase in value will be created by ensuring efficiency in production with both existing and new products.

In the analysis of the effects of corporate sustainability on company performance, it is a common type of analysis to compare companies that are engaged in social responsibility activities and published them under various names such as "Corporate Sustainability Report", "Corporate Social Responsibility Report", "Social Responsibility Report".

\section{Effects of Corporate Sustainability on Company Performance}

Unlike traditional growth and profitability of businesses, the so-called tribble bottom line theory emphasizes environmental, social and economic performance, and plays an important role in the realization of corporate sustainability, as well as the elements that are essential for its sustainability to be realized successfully (Karabulut, 2004):

- Growing and preserving products in high standards environments, following policies that will ensure efficient protection of land and forests,

- Continuous control of environmental pollution,

- $\quad$ Protection for plants and endangered animals,

- Learning and implementing successful environmental protection programs,

- Using resources in the form of optimum output, ensuring long-term efficiency,

- $\quad$ Foreseeing the problems that may arise and thus reducing the problems.

There are different ideas for the interaction between firms' environmental performance, social performance and financial performance. Empirical research on this subject supports this argument.

- According to Freidman (1970), social responsibility is costly and therefore argues that the firm's performance is deteriorated.

- $\quad$ Preston and O'Bannon (1997) and Jensen (2001) argue that social responsibility limits the value maximization of firms and may lead to weakening of financial performance (Ameer and Othman 2012).

- Ameer and Othman (2012) reviewed the top 100 global companies with sustainability practices at international level and rated their sustainability rating from 0 to 4. Accordingly, they tested hypothesis whether the impact of the first 100 companies with sustainability practices was reflected on their financial performance. 
Has identified a number of indicators to measure company performance. These are growth in sales, return on investment, profit before tax and cash flow of operating activities. It is examined whether there is a significant difference between the years of 2010-2018 in the first 100 companies in terms of the said performance. According to all statistical results, it is concluded that the return on investment, the financial performance measured by cash flow from pre-tax operating activities, the superior financial performance of sustainable finances increased by 2010-2012, 2013-2015 and 2016-2018 periods.

Accordingly, the highest return on investment, profit before tax and cash flow were obtained in 2010-2012 and 2016-2018 period. Despite sample size and time period limitations, all of these results provide reasonable evidence of a two-way relationship between corporate sustainability practices and financial performance.

\section{BIST Sustainability Index Methodological Investigation}

The purpose of the BIST Sustainability Index exchange traded in Istanbul and corporate sustainability performance of an index creation will take place in companies with a high level of understanding about sustainability, and in particular Istanbul Stock Exchange (BIST) companies in Turkey, is the increase of knowledge and practice (www.borsaistanbul.com).

The index will allow companies to compare their corporate sustainability performance locally and globally. With the Index, companies will be provided with a performance assessment tool to improve and set new targets, and to improve their corporate transparency and accountability, and their risk management skills related to sustainability issues. The Index will also provide a tool for investors to differentiate and invest in companies that adopt sustainability and corporate social responsibility (www.borsaistanbul.com).

In 2013, there has been an important development regarding sustainability reporting between İstanbul Stock Exchange (BIST) and Ethical Investment Research Services Limited (EIRIS), a cooperation agreement was signed to calculate the BIST Sustainability Index based on the companies' environmental, social and corporate management issues (Gözüm, and Acar, 2018). In this Agreement, EIRIS evaluates the companies by considering the international sustainability criteria, and companies exceeding the threshold values in the "Index Selection Criteria" determined within the scope of the studies conducted with EIRIS are included in the index by Istanbul Stock Exchange. The criteria that EIRIS takes into consideration in the valuation process; environment, biodiversity, climate change, human rights, supply chain, the structure of the company's board of directors, bribery, health and safety. (Gencoglu and Aytac, 2019).

In Istanbul Stock Exchange (BIST) companies, which are made objectively according to international usage criteria by EIRIS (Ethical Investment Research Services Limited Company), the valuation process is not made public, it is subject to it (Acar, 2018). EIRIS evaluates "all publicly available information" of companies and includes companies that exceed the "Index Selection Criteria" in the BIST Sustainability Index (BIST, 2014) 
In order to identify the companies to be included in the BIST Sustainability Index, the valuation of the companies included in the BIST 30 Index, which was carried out with EIRIS, was completed. In this context, the "Index selection criteria " has been declared by determining the number of companies in the scope of the BIST 30 environment, biodiversity, climate change, human right, board structure, anti-bribery, occupational health and safety According to the criteria, the companies in the BIST Sustainability index have been identified and the "Basic of the BIST Sustainability Indices" was established.

\section{BIST Sustainability Index Companies}

As of 4 November 2014, BIST Sustainability Index has been started to be calculated and published in terms of price and return with XUSRD code.

Table 1. BIST sustainability index, list of companies that was realized in 2019

\begin{tabular}{|c|c|c|c|}
\hline 1 AFYON & AFYON CIMENTO & 32 METRO & METRO HOLDING \\
\hline 2 AKENR & AK ENERJI & 33 MGROS & MIGROS TICARET \\
\hline $3 \quad \mathrm{AKBNK}$ & AKBANK & 34 NETAS & NETAS TELEKOM. \\
\hline $4 \quad$ AKSA & AKSA & 35 ODAS & ODAS ELEKTRIK \\
\hline $5 \quad$ AKSEN & AKSA ENERJI & 36 OTKAR & OTOKAR \\
\hline 6 ALBRK & ALBARAKA TURK & 37 PETKM & PETKIM \\
\hline $7 \quad$ ANACM & ANADOLU CAM & 38 POLHO & POLISAN HOLDING \\
\hline 8 AEFES & ANADOLU EFES & 39 SAHOL & SABANCI HOLDING \\
\hline 9 ANELE & ANEL ELEKTRIK & $40 \quad \mathrm{SKBNK}$ & SEKERBANK \\
\hline 10 ARCLK & ARCELIK & 41 SISE & SISE CAM \\
\hline 11 ASELS & ASELSAN & 42 SODA & SODA SANAYII \\
\hline 12 AYGAZ & AYGAZ TICARE & $43 \mathrm{SOKM}$ & SOK MARKETLER \\
\hline 13 BJKAS & $\begin{array}{l}\text { BESIKTAS FUTBOL } \\
\text { YAT. }\end{array}$ & 44 HALKB & T.C HALK BANKASI \\
\hline 14 BRISA & BRISA & 45 TSKB & T.S.K.B. \\
\hline 15 CEMTS & CEMTAS & $\begin{array}{ll}46 & \text { TATGD }\end{array}$ & TAT GIDA \\
\hline
\end{tabular}




\begin{tabular}{|c|c|c|c|}
\hline 16 CIMSA & CIMSA & 47 TAVHL & $\begin{array}{l}\text { TAV } \\
\text { HAVALIMANLARI }\end{array}$ \\
\hline 17 CCOLA & $\begin{array}{ll}\text { COCA } & \text { COLA } \\
\text { ICECEK } & \end{array}$ & 48 TKFEN & TEKFEN HOLDING \\
\hline 18 DOHOL & DOGAN HOLDING & 49 TOASO & TOFAS OTO. FAB. \\
\hline 19 DOAS & DOGUS OTOMOTIV & 50 TRKCM & TRAKYA CAM \\
\hline 20 ENJSA & ENERJISA ENERJI & 51 TUPRS & TUPRAS \\
\hline 21 ENKAI & ENKA INSAAT & 52 THYAO & TURK HAVA YOLLARI \\
\hline 22 EREGL & $\begin{array}{l}\text { EREGLI DEMIR } \\
\text { CELIK }\end{array}$ & 53 TTKOM & TURK TELEKOM \\
\hline 23 FROTO & FORD OTOSAN & 54 TTRAK & TURK TRAKTOR \\
\hline 24 GARAN & GARANTI BANKASI & 55 TCELL & TURKCELL \\
\hline 25 GLYHO & $\begin{array}{ll}\text { GLOBAL } & \text { YAT. } \\
\text { HOLDING } & \end{array}$ & 56 ULKER & ULKER BISKUVI \\
\hline 26 ISCTR & IS BANKASI (C) & 57 VAKBN & VAKIFLAR BANKASI \\
\hline 27 ISDMR & $\begin{array}{l}\text { ISKENDERUN } \\
\text { DEMIR CELIK }\end{array}$ & 58 VERUS & VERUSA HOLDING \\
\hline 28 KERVT & KEREVITAS GIDA & 59 VESTL & VESTEL \\
\hline $29 \mathrm{KCHOL}$ & KOC HOLDING & 60 VESBE & VESTEL BEYAZ ESYA \\
\hline $30 \quad$ KORDS & $\begin{array}{ll}\text { KORDSA } & \text { TEKNIK } \\
\text { TEKSTIL } & \end{array}$ & 61 YKBNK & $\begin{array}{lll}\text { YAPI } & \text { VE } & \text { KREDI } \\
\text { BANK. } & & \end{array}$ \\
\hline $31 \quad$ LOGO & LOGO YAZILIM & 62 ZOREN & ZORLU ENERJI \\
\hline
\end{tabular}

In January-March 2014 period, which is the first valuation period, the companies included in BIST 30 index were subjected to valuation. BIST Sustainability Index has an index period of one year, from November to October. "List of companies subject to valuation" is revised every year in December and announced by Istanbul Stock Exchange (BIST).

In order for the shares to be included in the index, the threshold values in the "Index Selection Criteria" must be exceeded. In order to encourage companies to increase their sustainability performance to higher levels, it is considered that the threshold values in the "Index Selection Criteria" will be gradually increased in the following years. 


\section{BIST Sustainable Index Contributions}

With the calculation of the index, companies that effectively manage their corporate risks and opportunities are provided with a competitive advantage, while an investable index can be developed on which new investment products can be developed to attract capital and finance to companies.

Index companies, global warming, depletion of natural resources, reduction of water resources, health, safety, the issues related to Turkey and the world as important for the sustainability of employment reveals how they approached.

The Index provides a tool for investors to distinguish between companies that adopt sustainability and corporate social responsibility principles and to invest in them, as well as an indication for asset managers for various financial products such as sustainabilitybased funds, stock exchange mutual funds and structured products.

Today, most of the responsible investments are made by institutional investors. The Sustainability Index will encourage the establishment of funds investing in this area and facilitate the participation of the companies included in the index (Krasniqi and Vardari, 2018).

Exchanges have a vital role in the development of sustainability in companies. Exchanges are not only responsible for the sustainability performance of companies, but are also an important force for companies to improve their sustainability performance.

The listed companies, which are publicly traded, have so far been obliged to provide annual financial reporting. Turkey Corporate Governance Association (TKYD) Chairman Mehmet immigrants in various meetings, as expressed so often, "Financial Reporting" by itself, does not actually means much more than talk look backwards from the rearview mirror. But what we really need is to report and communicate financial data and developments with environmental and social impacts. And so, talk to the future, not the past. To put it more clearly, the Annual Financial Report does not show whether all the financial data looks great, and the companies that transfer the milestones and profitability rates of their corporations for long years are under risk and their environmental and social impacts. We need to see that financial reporting, which is largely prepared for investors and unfortunately understood as a visual design" study, shows only the past of the institution in real terms (Vardari and Berisha, 2016).

However, investors do not invest in an institution's past, but in the future. Because every financial data seen in the report is past. It is no longer possible for a small or large investor to earn even a single penny. The report looks to decide whether or not to invest in the coming years, but these reports carry almost no information about it. Therefore, it is a document that conveys only past financial profitability, unfortunately nothing to tell.

\section{Methodology and Findings}

The aim of this study is whether the BIST Sustainable Index makes a difference for companies compared to BIST 100. Descriptive statistics and ADF tests were performed by comparing the closing data of the two indices and with the EViews 20 program. The data were collected from Borsa Istanbul and www.investing.com websites. 
The data includes the BIST Sustainable Index and the Stock Exchange closing data of the BIST 100 index between 2014 and 2018.

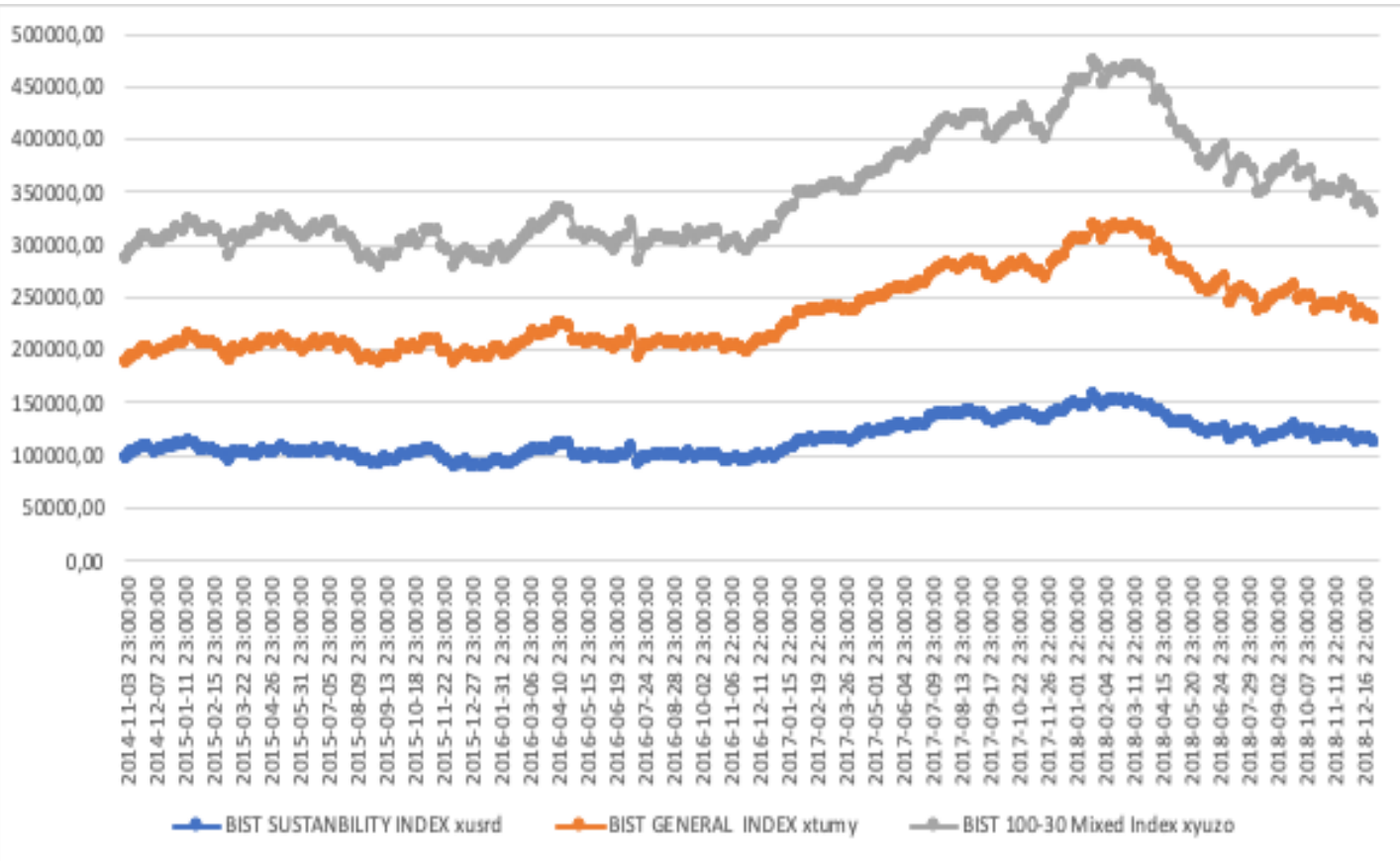

Figure 1. BIST-30 sustainability index and BIST-100 general index Performance

Source: finance.mynet.com

In Figure 1, data between 2014 and 2018 were used, the BIST sustainability index and the BIST 100 chart were created and analysis results $\mathrm{f}$ shows to us there is a indicating high degrees of positive correlation between XUSRD and two other indices: BIST 10030 (XYUZO) and BIST ALL-100 (XTUMY). BIST 100-30 index consists of 70 stocks in BIST 100 Index but not include in BIST 30 Index. The BIST General-100 index consists of the stocks of companies that are included in the BIST All Index but are not included in the BIST 100 Index, so sustainability index companies are not included in these two indexes. According to the graph we have obtained, we show that there is no big difference between BIST Sustainability index and other comparison indexes.

Table 2. BIST sustainability index and BIST-100 general index Performance

\begin{tabular}{|l|l|l|}
\hline & $\begin{array}{l}\text { BIST } \\
\text { INDEX }\end{array} \quad$ SUSTAINABILITY & $\begin{array}{l}\text { BIST } \\
\text { INDEX }\end{array}$ \\
\hline Mean & 113163.3 & 119392.5 \\
\hline Median & 107366.4 & 112183.9 \\
\hline Maximum & 155064.1 & 166307.4 \\
\hline Minimum & 88426.74 & 89620.27 \\
\hline Std. Dev. & 17200.83 & 19520.97 \\
\hline Skewness & 0.663489 & 0.675538 \\
\hline
\end{tabular}




\begin{tabular}{|l|l|l|}
\hline Kurtosis & 2.318193 & 2.453124 \\
\hline & & \\
\hline Jarque-Bera & 20.21704 & 19.29735 \\
\hline Probability & 0.000041 & 0.000065 \\
\hline & & \\
\hline Sum & 24669603 & 26027572 \\
\hline Sum Sq. Dev. & $6.42 \mathrm{E}+10$ & $8.27 \mathrm{E}+10$ \\
\hline & & \\
\hline Observations & 218 & 218 \\
\hline
\end{tabular}

Descriptive statistics of BIST Sustainability and BIST100 indices returns are given in Table 2. Accordingly, although the return of sustainability index is very low for the period of 2018, the return of the BIST100 index is higher than the BIST Sustainability index. On the other hand, the standard deviation of the returns of the BIST100 Index is slightly higher than the BIST Sustainability index. According to the Jarque-Bera test result, both returns are not normally distributed.

Table 3. Unit Root Test of BIST Sustainability and BIST 100 Indices Return Series

\begin{tabular}{|l|l|l|l|l|}
\hline \multirow{2}{*}{$\begin{array}{l}\text { Augmented Dickey- } \\
\text { Fuller test statistic }\end{array}$} & \multicolumn{3}{|l|}{ BIST SUTANIBILITY INDEX } & \multicolumn{2}{l|}{ BIST 100 INDEX } \\
\cline { 2 - 5 } & t-Statistic & Prob. & t-Statistic & Prob. \\
\cline { 2 - 5 } & -1.571421 & 0.01176 & -1.575974 & 0.01165 \\
\hline $1 \%$ Level & -3.460453 & -3.460453 & \\
\hline $5 \%$ Level & -2.874679 & -2.874679 & \\
\hline $10 \%$ Level & -2.573850 & -2.573850 & \\
\hline
\end{tabular}

Table 3 shows the ADF unit root test results. The ADF test can be BIST SU dropped and it is seen that the series is stationary when the BIST 100 index is analyzed with constant. For ADF, it is seen that $10 \%$ of the series has no root. For the BIST sustainable index and the BIST 100 index, the value of $1 \%$ has an effect. This tells us that it is appropriate to perform conditional volatility modeling of two return series. 

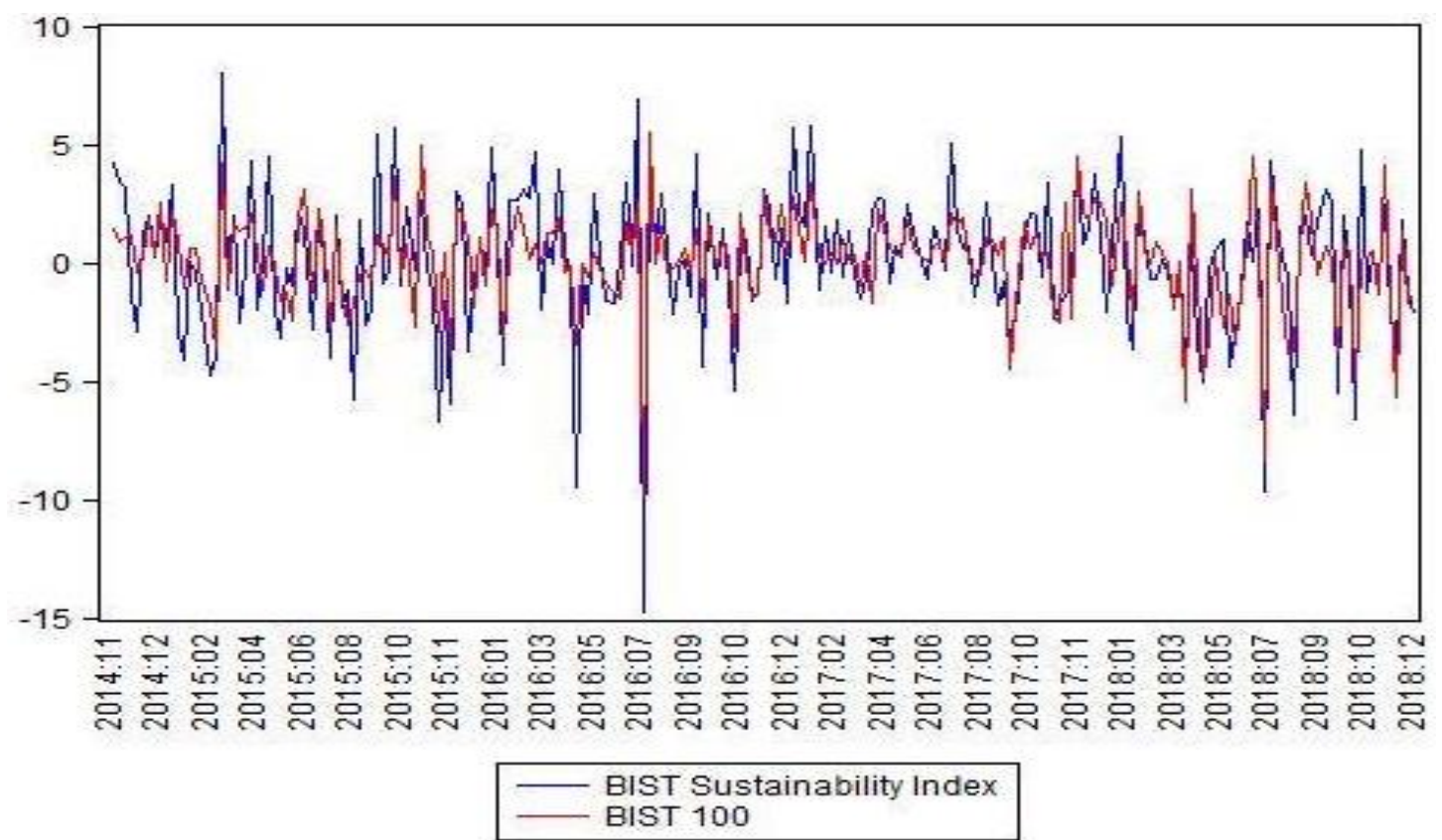

Figure 2. Conditional Volatility of Returns, BIST Sustainability and BIST100 Indices

Figure 2 shows the conditional volatility returns of the BIST Sustainability and BIST100 index. Accordingly, the returns of conditional volatility both indices are very close to each other and they exhibit a similar behavior.

\section{Conclusions and Recommendations}

The business world and all other stakeholders (public, civil society, academy, etc.) have been studying for many years what these changes and risks bring for themselves and are looking for solutions. Because human beings have given importance to economic development in order to increase the development level of countries for many years, but they have not realized the degradation and extinction and social balance. The greatest risk today is the possibility of starting a day in which we are faced with the fact that everything that is necessary for life, including all economic values, is gone, while in short demanding everything. For this reason, sustainability aims to be a more comprehensive field, although it is essential to business life, and it is the continuity of life on earth rather than being a business and public strategy.

Changing the strategies and ways of doing business, with the companies using the most resources and having the most impact on the environmental degradation, replacing some of the existing products with new and greener products are critical for the continuity of the economy. This change is a change that develops with the social pressure beyond the desires of the companies and brings important opportunities to the companies. Thus, the environment and society-friendly areas will be abandoned, the future vision, more environmentally friendly business models and products can be replaced and economic 
transformation will be achieved without collapse. Companies should be aware of this responsibility and environmental and social risks and have the ability to report their internal transformations in an ethical manner and in a transparent manner.

The BIST Index allows companies to compare their corporate sustainability performance locally and globally. The Index also provides a performance assessment tool to improve and set new targets, and to improve corporate transparency, accountability and risk management skills related to sustainability issues. It is thought that this will create a competitive opportunity for the companies and the recognition and reputation of the companies included in the index will increase.

According to the results we obtained, it was observed that there is a connection between BIST Sustainability Index and BIST 100 and the movements are interconnected. As stated in the first table, the returns and standard deviation of the BIST 100 index are slightly higher than the BIST Sustainable index, according to the Sustainability Index. In the $\mathrm{ADF}$ analysis, the returns between the two indices are fixed at $10 \%$ level, which makes it possible for us to calculate our volatility. The Volatility graph shown in Figure 3 also shows that there is not much difference between the two indices. Gök and Özdemir (2017) found similar results in their work. According to the findings in their study, the conditional volatility of both indices is very close to each other and they exhibit a similar behavior.

he current study is drafted based on the question "Does the BIST Sustainability Index really make a difference?" shows that the BIST sustainability index does not differ much from the BIST 100 index in our study. In fact, in their studies in Mumcu and Ufacik (2016), observed that they have accelerated their sustainability efforts to include them in the BIST Sustainability Index thanks to the BIST Sustainability Index. Also found that companies' sustainability efforts positively affect their missions, visions and strategies. reports to their financial reports. Similar conclusions were also drawn in the articles published in Yilmaz et al. (2020). The ethics obtained indicate that there is no strong evidence of the impact of inclusion or exclusion in the BIST Sustainability Index on stock returns and systematic risk (beta) of companies. However, it has been observed that participation in the BIST sustainability index decreases the total risk of the companies and the flexibility of the companies in the BIST Sustainability index during the crisis increases and their stock thinking is limited compared to the companies that do not exist. According to the study, they have accelerated the sustainability studies of the companies in order to comply with the BIST sustainability index, which in fact shows how important the BIST sustainability index is to the businesses. We believe that it will support them to make sufficient efforts in terms of sustainability.

\section{References}

Acar. P. (2018). "İşletmelerin BIST-Sürdürülebilirlik Endeksi’nde Yer Alma Durumuna Göre Üst Kademe Teorisi Kapsamında Değerlendirilmesi”. Istanbul Managemet Journal. 29(84): 93-112. DOI:10.26650/imj.2018.29.84.0006

Aktan. C. and Böru, D. (2007). "Kurumsal Sosyal Sorumluluk, isletmeler ve Sosyal Sorumluluk", Igiad Yaymlan: 4, S: 37-44. 
Amer, R. and Othman, R, (2012); "Sustainability Practises and Corporate Financial Performance: A Study Bascd on thc Top Global Corporations", Journal Business Ethics, s:61-79.

Bekmezci, M. (2014), " Strategies for Corporate Sustainability Journal of Management, Marketing \& Logistics. Vol. I-3.

Borsa Istanbul. (2014). Ş̣rketler için sürdürulebilirlik rehberi. Link: http://www.borsaistanbul.com/data/ kilavuzlar/surdurulebilirlik-rehberi.pdf adresinden edinilmiștir

Bozlogan, R. (2017) "Sürdürülebilir Gelisme Düsüncesinin Tarihsel Arka Plani", Sosyal Siyasat Konferanslan, Kitap 50.

Camhca, Z. and Akar, G. (2014), " Lojistik Sektöründe Sürdürülebilirlik Uygulamalan". Gümüshane Universitesi Sosyal Bilimler Elektronik Dergisi, v1.i1.

Cubuk, S. and Nabikoglu, Burak (2003); "Cevreci Pazarlama ve Tüketicilcrinin Cevreci Tutumlarumn Satin Alma Davramyna Etkileri ile ilgili Bir Uygulama" ,Cukurova Universitesi Sosyal Bilimler Enstitüsü Dergisi, C: 12 S: 12.

EIRIS. (2015). “Bist Sürdürulebilirliik Endeksī Araștirma Metodolojïsi”. Empowering Responsible Invetments.

Link:http://www.hakanguclu.com/wp-content/uploads/09-07.03.2016-BIST-Sürdürülebilirlik-EndeksiAraștırma-Metodolojisi.pdf

Genç,oglu, U:, G., Aytac, A. (2016). Kurumsal Sürdürulebilirlik Açsından Entegre Raporlamanın Önemi ve BIST Uygulamalar1. Muhasebe ve Finans Dergisi, 72, 51-66.

Friedman, M. (1970); "The social responsibility of business is to increase its profits Prospect", Bus. Ethics (1970), pp. 225-230.

Gök, İ., and Özdemir, O., (2017). The Performance Characteristic of Borsa Istanbul Sustainability Index. Sosyoekonomi, 25 (34), 87-105. DOI: 10.17233/sosyoekonomi.290838

Gomes, C. Kneipp, J., Kruglianskas, 1., Rosa,L., Bichueti,R. (2014), Management for sustainability in companies of the mining sector an analysis of the main factors related with the business performance, Journal of Cleaner Production 84, 84-93.

Gözüm, A. G. ve Acar, G. P. (2018), Isșetmelerin BIST-Sürdürulebilirlik Endeksi'nde yer alma durumuna göre üst kademe teorisi kapsaminda değerlendirilmesi. Istanbul Management Journal. Advance Online Publication. http://dx.doi.org/10.26650/imj.2018.29.84.0006

Ho, L., and Taylor, M. (2007). An empirical analysis of triple bottom-line reporting and its determinants: Evidence from the United States and Japan. Journal of International Finance Management and Accounting, 18(2), 123-150. Doi: 10.1111/j.1467646x.2007. 01010.x

IMKB Istatistik Müdürlügu, (2011), "Sürdürülebilirlikle ilgili Özet Bilgiler", ss.1-11.13

Jensen, Michael C. (2001). "Value Maximization, Stockholder Illusory. and the Corporate Objective Function". Ilarvurd Business School Research Paper, I (I).

Krasniqi D., Vardari L. (2018), "Corporate Sustainability Indexes: Dow-Jones Index". Journal of Accounting, Finance and Auditing Studies, Volume 4, Issue 4. Doi: 10.32602/jafas.2018.001

Lopez, V., Garcia. A. Rodriqucz, LÂ 2007), "Sustainable Development and Corporate Performance: A Study Based on the Dow Jones Sustainability Index ' ', Journal of Business Ethics, 75:285-300.

Lomno, R. (2012), “Towards better imbedding sustainability into companies' systems: An analysis of voluntary corporate Initiatives. Journal of Cleaner Production, 25(25), 14-26.

Karabulut, E. (2004), "Sürdürülebilir Kalkınma Anlayışının İşletmelerde Uygulanması", Tohis İş Hukuku ve İktisat Dergisi, Cilt: 19, Sayi I -2.

Kotler, P. and Lee,N, (2006). Kurumsal Sosyal Sorululuk (Çev. Sibel Kaçamak), İstanbul: McdİaCat.

Kotler, P. and Caslionc, J.A. (2011). Kaos Yönetimi (Çev. Kıvanç Dündar), İstanbul: Optimis

Kuşat, Nçö (2012). Sürdürülebilir İşletmeler İçin Kurumsal Sürdürülebilirlik ve İçsel Unsurları, Afyon Kocatepe Üniversitesi, İİBF Dergisi, C: 14, S:2.

Marimon, F., Alonso-Almeida, M. del M., Rodriguez, M. del P-, Cortcz Alejandro, K.A., 2012. The worldwide diffusion of the global reporting initiative: what İs the point? Journal of Cleaner Production 33, 132-144.

Mumcu, A., and Ufacik, O., (2016). A Research on Sustainability Indices: BIST Sustainability Index. Social and Economic Perspectives on Sustainability. International Sustainability Congress, Istanbul / Turkey. 
Özer, O, (2010), "Kurumsal Sürdürülebilirlik Ölçmü: Avrupa ve ABD Şirketlerinin Sektörel Bazda Karşılaştırılmalı Analizi”, Yıldız Teknik Üniversitesi SBE, Yayımlanmamış Yüksek Lisans Tezi, S: $1-90$.

Özçelik D. (2013), "Sürdürülebilirlik Performans Karnesi”, Journal of Yasar University, 30(8) 4985-500814

Öztel. A., Köse, M. S. and Aytekin, J. (2012), "Kurumsal Surdurebilirlik Performansinin Olculmesi icin Cok Kriterli Bir Cerceve: Ilengel Örnegi", Jarih KuItür ve Sanat Arasttmalan Dergisi. Volume 1, No.4. $32-44$.

Perez-Batres, L.A., Miller, V., Risani. M. (2011), "Institutionalizing sustainability: an empirical study of corporate registration and commitment to the United Nations global compact guidelines", Journal of Cleaner Production. Vol: 19. Issue.8. pages: 843-851.

Preston. L.E. and O'Bannon. D.P. (1997), “The corporate social-financial performance relationship: A typology and analysis". Business and Society Journal. 36(4), 419-429

Roca. L.C. and Searcy, C, (2012), "An Analysis of Indicators Disclosed in Corporate Sustainability Reports", Journal of Cleaner Productions, S: 103-1 18.

Senal. S. and Ates Arslantas, B. (2012), "Kurumsal Siirdürülcbilirlik iqin Muhascbe ve Raporlanmasl", Muhasebe ve Denetim Dergisi, Nisan 2012, Sayfa: 8397

Tokgöz, N and Önce S, (2009), "Sirket Sürdürülcbilirliki: Gelenekscl Yönetim Anlayjyna Altcrnatif", Afyon Kocatepe Üniversitesi, IIBF Dergisi. C.I 1, S. 1. 249-275.

Vardari L. Berisha B. (2016). "Balkan Countries Financial Markets Analysis and Economic Development Performance", International Journal of Management Sciences and Business Research, ISSN (22268235) Vol-5, Issue 3.

Wilson. M, (2003), "Corporate Sustainability: What is it and Where docs ir come from?", Ivey Business Journal.

Yildiz, T. (2006), "Rekabetin Degisen Trendleri ve Sürdürülebilir Kalkmma", Is Dünyasi ve Sürdürülebilir Kahnma Dernegi, TUSiAD Sbancl Universitesi, Il.Rekabet Callitayt , Sabanci Universitesi, Istanbul.

Yilmaz, M.K., Aksoy, M. (2020). "Tatoglu, E. Does the Stock Market Value Inclusion in a Sustainability Index? Evidence from Borsa Istanbul”. Sustainability, 12, 483. 